UDC 377.091.12:005.73

DOI: https://doi.org/10.31470/2415-3729-2020-11-214-231

\title{
Empirical Study of Organizational Culture Development of the Pedagogical Staff of the Vocational Educational Institution
}

\section{Tetiana Petrivna Polishchuk}

Director,

State Educational Institution «Berdychiv Higher Vocational School» $\triangle 1$ Lyceum Str., Velyki Nyzhirtsi, Berdychiv district, Zhytomyr region, Ukraine, 13304

E-mail: polischuk_t_p@ukr.net

ORCID: 0000-0002-5192-1921

Date of receipt of the article: April 11, 2020 Article accepted for publication: June 01, 2020

\section{Емпіричне дослідження розвитку організаційної культури педагогічного колективу закладу професійної освіти}

\section{Тетяна Петрівна Поліщук}

директор,

Державний навчальний заклад «Бердичівське вище професійне училище»

$\triangle$ вул. Ліцейна, 1, село Великі Низгірці, Бердичівський район, Житомирська обл., Україна, 13304

\footnotetext{
Дата надходження статті: 11 квітня 2020 р. Стаття прийнята до друку: 01 червня 2020 р.
}

\section{Abstract}

The aim of the article is to prove the organization and experimental testing results of the effectiveness of innovative methods of organizational culture development among the teaching staff of the vocational (vocational and technical) educational institution (V(VT) 
EI) of agricultural profile. The author characterises the interaction of the individual with society, the internal interaction of teachers, the interaction between managers and subordinates, resulting in the formation and development of teaching staff's organizational culture. The analysis of the facts obtained in the course of the research ascertaining stage regarding the status of organizational culture of $\mathrm{V}(\mathrm{VT}) \mathrm{EI}$, that is, participants of the experiment, is under focus.

The level of teaching staff's awareness of the mission, strategy, objectives, values, features of organizational culture of this category is clarified and described. The values that are formed by the professional experience and meet the interests of teachers are under emphasis. The specificities of the priority values of pedagogical collectives are revealed and their correlation with the values of the Ukrainian society, as well as with the European values, are clarified.

The main result of this study is a positive trend in the organizational culture development among the teaching staff of vocational (vocational and technical) educational institution of agricultural profile by all parameters demonstrated by a comparative analysis of the data obtained before the experiment and after the introduction of innovative methods. A clear example of this is the increase in the efficiency of the experimental V(VT)EI of the agricultural profile in areas such as the development of teachers' ability to carry out socially significant activities and to realize the intellectual potential, stability and unity of interpersonal relationships and interactions, which ensures the stability of the team, the coherence of intra-group interests.

Conclusions: 1. Based on values, organizational culture of the teaching staff promotes the interaction of the individual with society, pedagogical interaction between team members, between managers and subordinates, resulting in the formation and development of organizational culture of the teaching staff V(VT)EI of the agricultural profile. 2. The methods and technics developed and used in the course of the pedagogical experiment to study the status of organizational culture awareness by teachers can contribute to solution of managerial problems by the heads of the V(VT)EI. 
Key words: organizational culture; vocational (vocational and technical) educational institution of agricultural profile; pedagogical experiment; research and experimental work; axiological element.

\section{References}

1. Asherov, A.T. (2002). Podhotovka, ekspertyza y zashchyta dyssertatsyi [Preparation, examination and defense of dissertations]. Kharkov : UYPA [in Russian].

2. Hlumyn, P. \& Priadko, Y. (2011). Ukraynskyi dyahnoz [Ukrainian diagnosis]. Korrespondent, 9(446), 35 [in Russian].

3. Honcharenko, S.U. (2003). I nasampered - prykladna nauka [And first of all is applied science]. Khmelnytskyi : Vyd-vo Khmelnytskyi humanitarno-pedahohichnyi instytut [in Ukrainian].

4. Honcharenko, S.U. (2008). Pedahohichni doslidzhennia. Metodolohichni porady molodym naukovtsiam [Pedagogical research. Methodological advice for young scientists]. Kyiv ; Vinnytsia : DOV «Vinnytsia» [in Ukrainian].

5. Zhluktenko, V.I., Nakonechnyi, S.I. \& Savina, S.S. (2001). Teoriia ymovirnostei $i$ matematychna statystyka [Theory and Mathematical Statistics]. (Vol. 2. Matematychna statystyka). Kyiv : KNEU [in Ukrainian].

6. Zakharova, O.V. (2012). Aksiolohichnyi komponent pedahohichnoi systemy K. Deneka [Axiological component of K. Denek's pedagogical system]. Naukovi zapysky KDPU. Seriia : Pedahohichni nauky - Scientific notes of KSPU. Series: Pedagogical sciences. 112, 199-203 [in Ukrainian].

7. Moroz, L.V. (2015). Robocha prohrama «Osnovy psykholohii ta pedahohiky» dlia studentiv napriamu pidhotovky 6.140101 «Hotelnorestoranna sprava» [Work program «Fundamentals of Psychology and Pedagogy» for students]. Kyiv : KUTEP. Retrieved from http:// infopedia.su/5x8902.html [in Ukrainian].

8. Novykov, D.A. (2004). Statystycheskye metodi v pedahohycheskykh yssledovanyiakh (typovie sluchay) [Statistical methods in pedagogical research (typical cases)]. Moskva : MZ-Press [in Russian]. 
9. Polishchuk, T.P. (2016). Analiz stanu orhanizatsiinoi kultury pedahohichnykh kolektyviv PTNZ ahrarnoho profiliu [Analysis of the state of organizational culture of pedagogical staff of agricultural vocational schools]. Naukovyi chasopys Nats. ped. un-tu im. M.P. Drahomanova. Seriia 5 : Ped. Nauky : realii ta perspektyvy - Naukowyi Chasopys National Pedagogical Dragomanov University. Series 5. Pedagogical science: reality and perspectives, 54, 149-157 [in Ukrainian].

10. Polishchuk, T.P. (2018). Metodyka doslidzhennia problemy rozvytku orhanizatsiinoi kultury pedahohichnoho kolektyvu zakladu profesiinoi osvity ahrarnoho profiliu [Methods of research of a problem of development of pedagogical staff organizational culture at agricultural vocational schools]. Naukovyi visnyk Instytutu profesiino-tekhnichnoi osvity NAPN Ukrainy. Profesiina pedahohika - Scientific Herald of the Institute of Vocational Education and Training of the National Academy of Pedagogical Sciences of Ukraine. Vocational pedagogy, 15, 109-115 [in Ukrainian].

11. Polishchuk, T.P.(2018.) Orhanizatsiina kultura pedahohichnoho kolektyvu: faktory, umovy, motyvy rozvytku [Organizational culture of the teaching staff: factors, conditions, motives for development]. Proceedings of the XII All-Ukrainian Scientific and Practical Conference "Naukovo-metodychne zabezpechennia profesiinoi osvity $i$ navchannia» - «Scientific and methodological support of professional education and training». Kyiv : IPTO NAPN Ukrain, (pp. 199-201) [in Ukrainian].

12. Polishchuk, T.P.\&Svystun, V.I. (2015). Orhanizatsiina kultura pedahohichnoho kolektyvu profesiino-tekhnichnoho navchalnoho zakladu yak pedahohichna problema [Organizational culture of the pedagogical staff of a vocational school as a pedagogical problem]. Problemy osvity - Problems of education, 82, 224-230 [in Ukrainian].

13. Polishchuk, T.P. (2015). Funktsii orhanizatsiinoi kultury pedahohichnoho kolektyvu profesiino-tekhnichnoho navchalnoho zakladu ahrarnoho profiliu [Functions of organizational culture of pedagogical collective of vocational school of agrarian profile]. 
Profesiina osvita : problemy i perspektyvy - Vocational Education: Problems and Prospects, 8, (pp. 78-83) [in Ukrainian].

14. Snetkov, V.M. (2001). Modulno-funktsyonalnii analyz uspeshnosty deiatelnosty orhanyzatsyy [Modular-functional analysis of the success of the organization]. SPb. : Rech [in Russian].

15. Denek, K. \& Kuźniak, I. (2001). Projektowanie celów kształcenia $\mathrm{w}$ reformowanej szkole [Designing educational goals in a reformed school]. Poznań.

\section{Вступ}

У контексті сучасної моделі управління все більше увагу вітчизняних науковців i практиків привертає феномен організаційної культури. Суттєві напрацювання теоретичних i практичних аспектів організаційної культури закордонними (Ч. Бернард, П. Вейл, М. Далтон, Д. Денісон, К. Камерон, М. Коул, Р. Куїнн, Р. Льюїс, Д. Мацумото, У. Оучі, Е. Шейн) та українськими (О. Білецька, В. Болгаріна, Л. Карамушка, Г. Тимошко, О. Харчишина) вченими переконливо свідчать про необхідність, по-перше, радикальної зміни у сприйнятті організаційної культури установ і підприємств, й по-друге, цілеспрямованих досліджень теоретичних, організаційно-методичних та практичних аспектів розвитку організаційної культури в системі управління освітнім закладом i, зокрема, закладом професійної (професійно-технічної) освіти (Поліщук, 2016: 149-157).

Дослідник культури освіти Джером Брунер (Поліщук, 2018: 200) стверджує, що саме культура формує свідомість людини, а педагогіка дає засоби, методику іiі формування, вказує шляхи пізнання світу, окремих явищ і самого себе, своїх можливостей. Історія педагогічної теорії і практики невіддільна від способу культурного життя людей - освіта і $є$ культурою, а люди бувають різні - більш талановиті чи більш чесні, але головне - поставити їх в такі умови, створити їм таку мотивацію, щоб вони поводилися так, як вам це потрібно - саме так стверджують сучасні фахівці в галузі економіки і менеджменту (Глумин, Прядко, 2011: 35; Снетков, 2001: 447). 
Добре розвинена, міцна культура - найважливіша характеристика педагогічного колективу, адже вона передбачає стійкий зв’язок між культурою і стратегією діяльності освітнього закладу, призводить до єдності цілей усіх педагогів, забезпечує високу мотивацію та відповідальну участь у навчально-виховному процесі.

Організаційна культура педагогічного колективу кожного професійно-технічного освітнього закладу обумовлена ментальністю його особового складу, а також особливостями функціонування в конкретному регіоні. Так, особливості організаційної культури педагогічного колективу ЗП(ПТ)О аграрного профілю зумовлені специфічними умовами життєдіяльності в сільській місцевості, тому що вони, як правило, розташовані в селищах і селах, і своєрідність життєустрою сільського населення впливає на діяльність педагогічного колективу. Адже на селі люди добре знають один одного у всіх їх проявах, тому діяльність педагогів протікає в умовах підвищеного соціального контролю (Поліщук, 2015: 228-229; Поліщук, 2015: 78).

Німецький філософ і соціолог Макс Шелер (1874-1928), один iз фундаторів філософської антропології, виразно відокремлює «світ матеріальних благ від світу цінностей, які, на його переконання, існують незалежно від нас, є основними властивостями певних об'єктів і їх можна пізнати в акті безпосередньої інтуїції». Науковець переконує, що існує природна ієрархія цінностей: святість пізнання істини, справедливості, прекрасного; цінності вітальні - шляхетність, діловитість; найнижче розташовуються цінності споживацькі і гедоністичні (Захарова, 2011; Снетков, 2001: 447).

У гуманітарних науках поняття цінності «найчастіше відноситься до того, що цінує людина або суспільна група; що вважається за важливе і в такий спосіб переживається; цінність означає все те, що не є природним і байдужим, але є важливим і значущим, а тому є метою для людських прагнень» (Denek\&Kuźniak, 2001: 23). Певна річ, цінності відіграють роль орієнтира у поведінці і життєдіяльності людини в соціумі. Кожен із нас орієнтується 
на цінності, які відповідають інтересам і поставленим цілям, які сформовані набутим досвідом професійної діяльності.

Актуальність дослідження зумовлена відсутністю відсутність методів діагностики розвитку організаційної культури ЗП(ПТ)О аграрного профілю у наукових роботах українських дослідників і потребою її використання керівниками освітніх закладів у практиці управління навчально-методичною діяльністю педагогічного колективу такої установи.

Виходячи з зазначеного вище, метою статті є обгрунтування організації та результатів експериментальної перевірки результативності інноваційної методики розвитку організаційної культури педагогічного колективу ЗП(ПТ)О аграрного профілю.

\section{Матеріали і методи досліджень}

Дослідження засноване на розкритті змісту організаційної культури педагогічного колективу як важливого ресурсу вдосконалення діяльності ЗП(ПТ)О аграрного профілю, і визначенні функцій організаційної культури та іï особливостей на основі аналізу та узагальнення сучасних наукових джерел, з урахуванням специфіки функціонування системи професійної (професійнотехнічної) освіти (П(ПТ)О) в Україні.

Аналізуючи підходи науковців(О. Білецька, В. Болгаріна, Л. Карамушка, Г. Тимошко, О. Харчишина) щодо розуміння суті і структури організаційної культури, проведено паралель 3 педагогічною культурою, з'ясовано особливості розвитку організаційної культури педагогічного колективу, заснованої на цінностях.

Засобами експериментальної роботи визначено рівень розвиненості організаційної культури в педагогічних колективах ЗП(ПТ)О аграрного профілю та з'ясовано обізнаність педагогічних працівників щодо місії, стратегії, цілей, цінностей, проведено діагностування стану розвиненості організаційної культури на початкових етапах дослідження.

\section{Результати та їх обговорення}

Огляд використаної для дослідження літератури здійснено за рекомендаціями А. Ашерова (Ашеров, 2002: 90). Опрацьовано до- 
кументи міжнародного, державного рівня, що надають уявлення про стратегію розвитку професійної освіти і навчання, нормативноправового забезпечення запроваджуваних реформ. Також розглядались концептуальні положення філософських теорій, на засадах яких планувалась робота експериментального закладу з розвитку організаційної культури.

Сам процес дослідження розвитку організаційної культури педагогічного колективу ЗП(ПТ)О аграрного профілю охоплював три етапи науково-педагогічного пошуку.

Результати опитування (тести, анкети) дали підстави для визначення потреб членів педагогічних колективів і напрямів, за якими необхідно розвивати організаційну культуру ЗП(ПТ)О - це здатність педагогічного колективу здійснювати суспільно значиму діяльність й реалізувати інтелектуальний потенціал педагогічних працівників, стійкість i єдність міжособистісних взаємин i взаємодій, що забезпечує стабільність діяльності колективу, узгодженість внутрішньо групових інтересів. У ході дослідження перевірялась результативність інноваційної методики розвитку організаційної культури педагогічного колективу ЗП(ПТ)О аграрного профілю (Поліщук, 2018: 113).

3 метою визначення обсягу генеральної сукупності встановлена загальна кількість 3П(ПТ)О України - 243, в яких здійснюється підготовка робітників за професіями аграрного профілю. У педагогічному експерименті взяли участь 11 3П(ПТ)О із семи областей України (Житомирська, Дніпропетровська, Закарпатська, Київська, Вінницька, Черкаська, Хмельницька) із загальною кількістю педагогічних працівників 511 осіб.

На теоретико-діагностичному етапі дослідження здійснювалось теоретичне вивчення стану розробленості проблеми у філософській, педагогічній, культурологічній, економічній, психологічній, соціологічній галузях наук.

На констатувальному етапі дослідно-експериментальної роботи з використанням комплексу методів було визначено рівень сформованості організаційної культури в педагогічних колекти- 
вах зазначених 3П(ПТ)О за критеріями (ознаки, привабливість культури, змістовна характеристика, готовність до самоосвіти та саморозвитку, тип організаційної культури) та виокремлено їі особливості. 3' ясовано обізнаність педагогічних працівників щодо місії, стратегії, цілей освітнього закладу.

Вивчення стану сформованості організаційної культури ЗП(ПТ)О аграрного профілю відбувалось методом опитування (анкетування, тестування, інтерв'ю), і це дало можливість діагностувати стан існуючої організаційної культури в закладах освіти, які брали участь в експерименті. На основі аналізу отриманих результатів проектувались напрями, технології, умови педагогічного експерименту.

На формувальному етапі експерименту перевірялась динаміка розвитку організаційної культури за двома критеріями: 1) привабливість існуючої в педагогічному колективі організаційної культури; 2) готовність педагогів до самоосвіти та саморозвитку.

Тестування за опитувальником «Привабливість існуючої в педагогічному колективі культури» (Снетков, 2001: 447), адаптованого і заснованого на аксіологічному (ціннісному) компоненті, теж $є$ предметом дослідження 3 урахуванням закономірності взаємозв'язку та взаємообумовленості загальнокультурних, організаційних та педагогічних цінностей. У даному опитуванні учасникам експерименту було запропоновано 40 тверджень, для прикладу наводимо окремі 3 них: про мою роботу не соромно розповісти друзям та знайомим; робота дозволяє мені проявити свою індивідуальність, свої найкращі якості; усі педагоги володіють достатньою інформаичєю про те, щзо робиться у навчальному закладі, про ичілі та плани його розвитку; усі педагогічні працівники налаштовані на досягнення цілей навчального закладу; перед кожним підрозділом (предметна, методична комісія) завжди ставляться конкретні иілі та завдання; робота безпечна, не загрожує здоров 'ю та життю; більш досвідчені й стариі педагоги постійно надають підтримку менш досвідченим і молодим; моя робота є важливою складовою діяльності педагогічного колекти- 
ву та ін., по кожному 3 яких учасники опитування давали відповідь по шкалі від 0 до 5. Кількість учасників опитування - 204 особи. Для кожного із 40 запитань середнє значення оцінки (балу) було закладено середнє квадратичне відхилення до та після експерименту та емпіричне значення критерію.

Методикількісноготаякісногоаналізудозволили діагностувати існуючий стан організаційної культури педагогічних колективів ЗП(ПТ)О. Засобом методу рангової кореляції відслідковувалась пріоритетність цінностей педагогічних колективів, їх спрямованість на розвиток організаційної культури всередині колективу. Наприклад, перелік базових цінностей вибудовано за методикою, розробленою Ш. Шварцем, ізраїльським вченим, широко відомим за дослідженнями загальноєвропейського рівня (Глумин, 2011; Прядко, 2011: 35). Опитування і здійснений після нього аналіз, що проводились в рамках експерименту з використанням цих показників у ряді колективів 3П(ПТ)О показали, як педагогічні працівники розподіляють цінності за пріоритетами:

- конформність була винесена на перші місця у 84 \% опитаних як така, що може сприяти власній безпеці та певній стабільності;

- безпека виявилась серед найважливіших у 61,3 \% опитаних;

- влада - цікаво, що майже третина учасників експерименту називають іï серед важливих цінностей. Це показує ставлення до влади, як джерела матеріального благополуччя, привілеїв та безпеки (Глумин, Прядко, 2011: 35).

Перевірку суттєвості впливу запровадженої інноваційної методики розвитку організаційної культури педагогічного колективу ЗП(ПТ)О аграрного профілю було проведено з використанням тесту Крамера-Уелча (Жлуктенко, Наконечний, Савіна, 2001: 336) Цей статистичний критерій дає змогу перевірити гіпотезу про рівність середніх значень для двох сукупностей. У процесі проведення вказаного тесту використовувались такі статистичні характеристики, як середнє значення та середнє квадратичне відхилення вибірки згідно формул для розрахунку статистичних показників. 
Значно змінилась середня оцінка за показником «кожен педагогічний працівник має можливість підвищити свою кваліфікацію 3 3,52 до 3,68 бала. Педагогічні працівники самі стали знаходити інформацію про цікаві для них конференції, семінари, тренінги, обирати теми для захисту після проходження курсів підвищення кваліфікації, більш відповідально виконувати ці роботи, використовувати їх результати в практичній діяльності.

Позитивну динаміку можна спостерігати за показником «кожен педагог шукає способи підвищення рівня ефективності надання навчальним закладом освітніх послуг» - середня оцінка ( з 3,12 до 3,31 бала). Викладачі ЗП(ПТ)О значно збільшили увагу щодо добору змісту навчання в межах, визначених нормативними документами, його постійному оновленню відповідно до вимог ринку праці; вибору адекватних методів професійного навчання і запровадженні інформаційно-комунікаційних технологій; впровадженню компетентнісного, культурологічного та інших наукових підходів.

Тест Крамера-Уелча було використано також для обчислення результатів різниці відносних частот у визначенні рівнів готовності педагога до самоосвіти та саморозвитку (анкета «Оцінка рівня готовності педагога до самоосвіти та саморозвитку» до та після формувального етапу експерименту включає 19 тверджень). Наводимо деякі з них: я читав і маю знання про принщипи, методи, правила самоосвіти, самовиховання, саморозвитку особистості; я відчуваю прагнення глибше пізнати самого себе, свої творчі здібності; я знаю свої сильні і слабкі сторони; я прагну виховувати в собі силу волі та інші якості; колеги вважають мене здатним до самоосвіти тощо.

Результати формувального етапу експерименту засвідчили зростання прагнень педагогів до самоосвіти і самовиховання (середня оцінка зросла з 1,98 до 2,2). У більшості з'явилася впевненість у собі, що стало проявлятися в критичному ставленні до своїх вчинків і результатів діяльності (середня оцінка змінилась 3 1,68 до 2,34), взаємодії з учнями, їх батьками і колегами, здатності уникати 
конфліктних ситуацій (спостерігаються зрушення середньої оцінки з 1,64 до 2,38) і готовності до ризику в прийнятті рішень. Останній показник продемонстрував зростання середньої оцінки 3 1,66 до 2,39. Позитивну динаміку змін у самооцінці та об'єктивності в оцінюванні діяльності колег демонструє зростання середньої оцінки - 31,75 до 2,31.

У процесі аналізу тесту «Оцінка рівня готовності педагога до самоосвіти та саморозвитку», а також відповідно до визначених методик (за Л.В. Мороз (Мороз, 2015)), рівень самооцінки поділяють на низький (19-25 балів), середній (26-38 балів), достатній (3949 балів), високий (50-57 балів). Тобто маємо порядкову шкалу 3 кількістю рівнів $L=4$ (табл. 1).

Для перевірк и однорідності вибірок до та після проведення експерименту використовуємо критерій $\chi^{2}$. Отже, 3 рівнем надійності 0,95 приймаємо гіпотезу про суттєвість відмінностей результатів опитування до та після проведення експерименту. Використання інноваційної методики як складової моделі розвитку організаційної культури педагогічного колективу, що була використана в спеціально створених педагогічних умовах, дала можливість підвищити ефективність діяльності експериментального ЗП(ПТ)О аграрного профілю.

Таблиия 1

Результати перевірки однорідності вибірок рівнів розвитку організаційної культури педагогічного колективу до та після проведення формувального етапу експерименту

\begin{tabular}{|c|c|c|c|c|c|c|c|c|}
\hline \multicolumn{5}{|c|}{ До експерименту } & \multicolumn{5}{c|}{ Після експерименту } & Кількість & $\%$ & Різниця \\
\hline Рівень & Бали & Кількість & $\%$ & Рівень & Бали & & & \\
\hline Низький & $19-25$ & 19 & 9,31 & Низький & $19-25$ & 0 & 0,00 & 9,31 \\
\hline Середній & $26-38$ & 100 & 49,02 & Середній & $26-38$ & 72 & 35,29 & 13,73 \\
\hline Достатній & $39-49$ & 85 & 41,67 & Достатній & $39-49$ & 118 & 57,84 & 16,17 \\
\hline Високий & $50-57$ & 0 & 0,00 & Високий & $50-57$ & 14 & 6,86 & 6,86 \\
\hline Всього: & & 204 & 100 & & & 204 & 100 & \\
\hline
\end{tabular}


За підсумками порівняльного аналізу отриманих даних до початку експерименту і після запровадження інноваційної методики зафіксовано позитивну динаміку розвитку організаційної культури педагогічного колективу ЗП(ПТ)О аграрного профілю за всіма показниками. Проведені обчислення із застосуванням тесту Крамера-Уелча дозволяють із ймовірністю 0,95 стверджувати про іiі результативність.

У свою чергу статистичні дані перевірки однорідності вибірок рівнів розвитку організаційної культури педагогічного колективу до та після проведення формувального етапу експерименту з використанням критерію Пірсона $\chi^{2}$ з рівнем надійності 0,95 підтверджують суттєвість відмінностей результатів опитування до та після проведення експерименту (Новиков, 2004: 67).

Безумовно, це позитивно вплинуло на якість організації освітнього процесу та на результати професійної підготовки майбутніх кваліфікованих робітників. При цьому керівництво освітнього закладу навчилось ставити конкретні цілі перед педагогами, у зв'язку з чим зросла кількість опитаних, які почали свідомо підходити до опанування новітніх технологій підготовки кваліфікованих робітників; підвищився рівень командної роботи в колективі, а це позитивно проявилось у таких аспектах діяльності педагогічного колективу: у самостійному визначенні цілей стосовно виконання конкретних завдань; у розподілі обов'язків у групі; в організації взаємодопомоги; в обговоренні будьяких пропозицій та прийнятті консенсусних і раціональних рішень; у сприйнятті конфліктів, як можливості генерації нових ідей; у постійному обміні інформацією тощо. Більш раціонально став використовуватися робочий час усіх суб'єктів освітнього процесу, покращились показники розвитку професійної компетентності педагогів, керівного персоналу, водночас посилилась упевненість у завтрашньому дні, у розвитку закладу освіти, у збереженні робочого місця.

\section{Висновки}

Проблема організаційної культури педагогічного колективу ЗП(ПТ)Оаграрного профілюранішенедосліджувалась, відповідно в педагогічній теорії і практиці відсутні технології їі розвитку. Якісна оцінка цього унікального явища розкриє відповідність да- 
ного дослідження існуючим потребам, очікуванням і цінностям. Тому можемо стверджувати, що основна мета педагогічного експерименту досягнута: перевірено, всебічно вивчено і обгрунтовано поставлені завдання дослідження.

Заснована на цінностях, організаційна культура педагогічного колективу сприяє взаємодії особистості з соціумом, педагогічній взаємодії між членами колективу, між керівництвом і підлеглими, у результаті чого відбувається формування і розвиток організаційної культури педагогічного колективу 3П(ПТ)О аграрного профілю.

У ході дослідження виявлено та обгрунтовано специфіку розвитку організаційної культури педагогічного колективу ЗП(ПТ)О аграрного профілю.

\section{Список використаних джерел}

1. Ашеров А.Т. Подготовка, экспертиза и защзита диссертациий : учебн. пособ. Харьков : УИПА, 2002. 135 с.

2. Глумин П., Прядко И. Украинский диагноз. Корреспондент. № 9 (446). 2011. С. 35.

3. Гончаренко С.У. I насамперед-прикладна наука. Хмельницьький : Вид-во Хмельницький гуманітарно-педагогічний інститут, 2003. $20 \mathrm{c}$.

4. Гончаренко С.У. Педагогічні дослідження. Методологічні поради молодим науковцям. Київ ; Вінниця : ДОВ «Вінниця», 2008. $278 \mathrm{c}$.

5. Жлуктенко B.I., Наконечний C.I., Савіна C.C. Теорія ймовірностей $і$ математична статистика : навч.-метод. посіб. у 2-х ч. Ч. II. Математична статистика. Київ : КНЕУ, 2001. 336 с.

6. Захарова О.В. Аксіологічний компонент педагогічної системи К. Денека. Наукові записки КДПУ. Серія : Педагогічні науки. Кіровоград : КДПУ, 2012. Вип. 112. С. 199-203.

7. Мороз Л.В. Робоча програма «Основи психології та педагогіки» для студентів напряму підготовки 6.140101 «Готельноресторанна справа». Київ : КУТЕП, 2015. 66 с. URL: http://infopedia. su/5x8902.html. 
8. Новиков Д.А. Статистические методы в педагогических исследованиях (типовые случаи). Москва : МЗ-Пресс, 2004. 67 с.

9. Поліщук Т.П. Аналіз стану організаційної культури педагогічних колективів ПТНЗ аграрного профілю. Науковий часопис Нац. пед. ун-ту ім. М.П. Драгоманова. Серія 5 : Пед. Науки : реалії та перспективи : зб. наук. пр. Київ, 2016. Вип. 54. C. 149-157.

10. Поліщук Т.П. Методика дослідження проблеми розвитку організаційної культури педагогічного колективу закладу професійної освіти аграрного профілю. Науковий вісник Інституту професійно-технічної освіти НАПН Украӥни. Професійна педагогіка : зб. наук. пращ̧ь : Вид. Євенок О.О., Вип. 15. 2018. С. 109-115.

11. Поліщук Т.П. Організаційна культура педагогічного колективу : фактори, умови, мотиви розвитку. Науково-методичне забезпечення професійної освіти і навчання : зб. матеріалів ХII звіт. всеукр. наук.-практ. конф. (м. Київ, 5-19 березня 2018 р.) / Ін-т проф.-техн. освіти НАПН України ; за заг. ред. В.О. Радкевич. Київ : ІПТО НАПН України, 2018. С. 199-201.

12. Поліщук Т.П., Свистун В.I. Організаційна культура педагогічного колективу професійно-технічного навчального закладу як педагогічна проблема. Проблеми освіти : наук. зб. / Ін-т інновац. технол. і змісту освіти. Вінниця, Київ, 2015. Вип. 82. С. 224-230.

13. Поліщук Т.П. Функції організаційної культури педагогічного колективу професійно-технічного навчального закладу аграрного профілю. Професійна освіта : проблеми $i$ nерспективи : зб. наук. пр. / Ін-т проф.-техн. освіти НАПН України. 2015. № 8. C. 78-83.

14. Снетков В.М. Модульно-функциональный анализ успешности деятельности организации. Практикум по психологии менеджмента и профессиональной деятельности : СПб. : Речь, 2001. C. 447.

15. Denek K., Kuźniak I., Projektowanie celów kształcenia w reformowanej szkole. Poznań. 2001. s. 12. 


\section{Поліщук Т.П.}

\section{Емпіричне дослідження розвитку організаційної культури педагогічного колективу закладу професійної освіти}

\section{Анотація}

Метою статті $\epsilon$ обгрунтування організації та результатів експериментальної перевірки результативності інноваційної методики розвитку організаційної культури педагогічного колективу закладу професійної (професійно-технічної) освіти (ЗП(ПТ)О) аграрного профілю. Охарактеризовано взаємодію особистості 3 соціумом, взаємодію педагогів всередині колективу, взаємодію між керівництвом і підлеглими, у результаті чого відбувається формування і розвиток організаційної культури педагогічного колективу. Важливу роль відведено аналізу фактів, отриманих у процесі констатувального етапу дослідження стану організаційної культури ЗП(ПТ)О - учасників експерименту.

3'ясовано та описано рівень обізнаності педагогічних працівників щодо місії, стратегії, цілей, цінностей, особливостей організаційної культури вказаної категорії. Акцентовано увагу на цінностях, які сформовані досвідом професійної діяльності i відповідають інтересам педагогів. Розкрито особливості пріоритетних цінностей педагогічних колективів і з'ясовано, як вони співвідносяться із цінностями українського суспільства, а також з європейськими цінностями.

Основні результати даного дослідження полягають в тому, що порівняльний аналіз отриманих даних до початку експерименту i після запровадження інноваційної методики показує позитивну динаміку в розвитку організаційної культури педагогічного колективу закладів професійної (професійно-технічної) освіти аграрного профілю за всіма показниками, що вимірювалися. Яскравий тому приклад - підвищення ефективності діяльності експериментального ЗП(ПТ)О аграрного профілю за такими напрямами, як розвиток здатності педагогів здійснювати суспільно значиму діяльність 
й реалізовувати інтелектуальний потенціал, стійкість і єдність міжособистісних взаємин і взаємодій, що забезпечує стабільність діяльності колективу, узгодженість внутрішньо групових інтересів.

Висновки: 1. Заснована на цінностях, організаційна культура педагогічного колективу сприяє взаємодії особистості з соціумом, педагогічній взаємодії між членами колективу, між керівництвом і підлеглими, у результаті чого відбувається формування і розвиток організаційної культури педагогічного колективу ЗП(ПТ)О аграрного профілю. 2. Розроблені та використані в ході педагогічного експерименту методи і методики дослідження стану розуміння педагогами організаційної культури можуть сприяти розв'язанню керівниками ЗП(ПТ)О управлінських проблем.

Ключові слова: організаційна культура; заклад професійної (професійно-технічної) освіти аграрного профілю; педагогічний експеримент; дослідно-експериментальна робота; аксіологічний компонент.

\section{Полищук Т.П.}

\section{Эмпирические исследования развития организационной куль- туры педагогического коллектива учреждений профессио- нального образования}

\section{Аннотация}

В статье представлено организацию и ход экспериментальной проверки инновационной методики развития организационной культуры педагогического коллектива.

Выяснено и описано уровень осведомленности педагогов относительно миссии, стратегии, целей, ценностей, особенностей организационной культуры указанной категории.

В процессе формирующего этапа эксперимента акцентировано внимание на ценностях, которые сформированы опытом профессиональной деятельности и соответствуют интересам педагогов, а также выяснено, как они соотносятся с европейскими ценностями. 
Статистическая обработка и сравнительный анализ полученных данных до эксперимента и после внедрения инновационной методики показали позитивную динамику в развитии организационной культуры по всем показателям, которые измерялись. Разработанные и использованные методы исследования могут способствовать решению управленческих проблем.

Ключевые слова: организационная культура; заведение профессионального образования аграрного профиля; педагогический эксперимент; опытно-экспериментальная работа; аксиологический компонент. 